\title{
Multi-Scale Organization of the Doumbouo-Fokoué Bauxites Ore Deposits (West Cameroon): Implication to the Landscape Lowering
}

\author{
Mathieu Nouazi Momo ${ }^{1}$, Paul Tematio ${ }^{1 *}$, Martin Yemefack ${ }^{2}$ \\ ${ }^{1}$ Department of Earth sciences, University of Dschang, Dschang, Cameroon \\ ${ }^{2}$ Institut de Recherche Agronomique pour le Développement (IRAD), Yaoundé, Cameroun \\ Email: "paul_tematio@yahoo.fr
}

Received September 14, 2011; revised October 28, 2011; accepted December 3, 2011

\begin{abstract}
Landscape distribution, macroscopic, microscopic, mineral and geochemical characterizations were conducted on the Doumbouo-Fokoué bauxite ore deposit in order to estimate bauxites potential and its implication to general lowering of the relief. Fourteen bauxitic plateaus covering a surface area of $5.7 \mathrm{~km}^{2}$ were identified. Bauxitic pedons show deep weathered profiles $(10.0-12.0 \mathrm{~m})$ with thick bauxitic mantle $(4.0-8.0 \mathrm{~m})$. Saprolite and pisolith bauxitic facies own high aluminium $\left(47.5 \%-49.5 \% \mathrm{Al}_{2} \mathrm{O}_{3}\right)$, relatively low iron $\left(20.0 \%-22.0 \% \mathrm{Fe}_{2} \mathrm{O}_{3}\right)$ and low silica contents $(1.8 \%$ $7.6 \% \mathrm{SiO}_{2}$ ). Gibbsite is the dominant mineral ( $49 \%$ - $68 \%$ of minerals detected by X-ray); meanwhile hematite, goethite and kaolinite occur in small amounts. Bauxitization corresponds to intense allitization with abundant accumulation of gibbsite and development of lateritic iron bearing ortho-bauxites. Bauxite ores yielded bauxite reserves of 9.2 million tons. They occur as old and residual bauxitic mantles representing remnants of the Miocene residual lateritic deposits in West Cameroon referring to the African surface of Valeton [1]. Its mean altitude (1532 - $1590 \mathrm{~m}$ als) below the African surface reveals general lowering of the relief.
\end{abstract}

Keywords: Bauxitic Plateaus; Saprolite Facies; Pisolith Facies; Relief Lowering; West Cameroon

\section{Introduction}

Bauxites are residual (lateritic bauxites) or sedimentary (karsts bauxites) rocks with more than $40 \%$ of $\mathrm{Al}_{2} \mathrm{O}_{3}$ and less than $8 \%$ of $\mathrm{SiO}_{2}$ [2] known as the main provider of aluminium. World bauxite resources are estimated around 75 billion tons [3], mainly in Africa (33\%), Oceania (24\%), South America and the Caribbean (22\%), and Asia (15\%). In West and Central Africa, lateritic bauxites are widespread and were developed especially in Guinea, Mali, Burkina-Faso, Ivory-Cost, Ghana, Nigeria and Cameroon where more than 60 ores deposits are now inventoried [4].

In Cameroon, works on laterites in general, and lateritic bauxites in particular, started at the $\mathrm{b}$ eginning of the $20^{\text {th }}$ century [5-11]. The majority of these studies were focussed on the characterization and the evaluation of the well known bauxites ores deposits in MinimMartap and Ngaoundal-Ngaoundouro in the Adamaoua region and Fongo-Tongo and Bagam in the West region. They noted that Cameroon has the $6^{\text {th }}$ world bauxite reserves with approximately 1.5 billion tons. This amount

${ }^{*}$ Corresponding author. seems to be underestimated since there still be many non explored bauxitic indices in Cameroon as indicated by the SABAP exploration licence [7] and the recent geological map of Cameroon [12]. The Doumbouo-Fokoué area contains one of these non explored bauxitic indices of Cameroon. The main objective of this study is to characterize the bauxitic facies of Doumbouo-Fokoué at different scales in order (i) to estimate the bauxites potential in this area and (ii) to correlate bauxites landscape distribution and evolution in this region with the general lowering of the relief in the West Cameroon Highlands. Results may contribute to increase the Cameroon bauxite reserves, examine in detail bauxitization process in the West Cameroon Highlands and correlate these bauxite ore deposits to the well known bauxites ore deposits in Cameroon and Africa.

\section{Materials and Methods}

\subsection{The Site Setting}

The Doumbouo-Fokoué region is located between longitudes $10^{\circ} 05^{\prime}$ and $10^{\circ} 08^{\prime}$ East and latitudes $5^{\circ} 21^{\prime}$ and $5^{\circ} 27^{\prime}$ North (Figure 1). Morphologically, it belongs to 


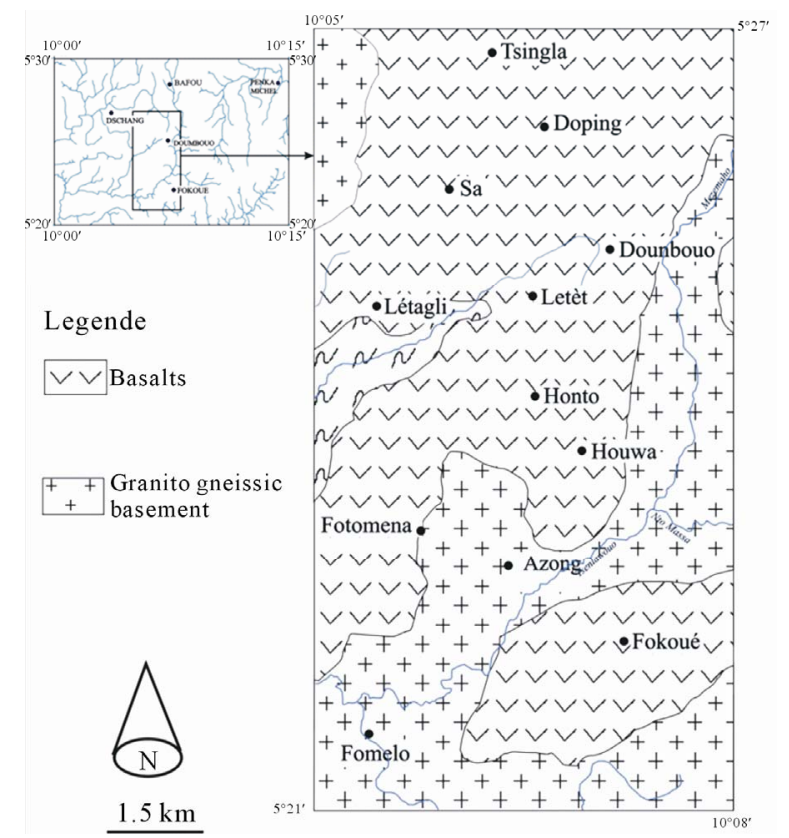

Figure 1. Geological map and localization of DoumbouoFokoué region.

the Bamiléké plateau (small insert in Figure 1) which corresponds to the south-western part of the West Cameroon Highlands with mean altitude $1400-1600 \mathrm{~m}$ asl. Very elongated interfluves with convex slopes are the dominant features in this region.

The Doumbouo-Fokoué region is deeply dissected by a dense hydrographic network which belongs to the Ménoua watershed. It is under sub-equatorial climate of high altitude characterized by a long rainy season from March to October and short dry season from November to February. The mean annual rainfall is $1755 \mathrm{~mm}$ and the mean annual temperature is $20^{\circ} \mathrm{C}$.

From the geological point of view, the DoumbouoFokoué region belongs to the Cameroon volcanic line $(C V L)$ [13] that crosses the western part of the Cameroon territory. It includes Cenozoic volcanic complexes overlying on the Neo-proterozoic panafrican granito- gneissic units (Figure 1) [14]. In this region, the bauxite ores deposits are developed exclusively from the Miocene aphyric or porphyric basalts [15]. They are composed predominantly of laths of plagioclase $\left(\mathrm{An}_{46-72}\right)$, coarse to fine grains of forsterite $\left(\mathrm{Fo}_{66-87}\right)$, augite and diopside. $\mathrm{Fe}-\mathrm{Ti}$ oxides occur as accessory minerals and $\mathrm{Cr}-\mathrm{Fe}$ spinels as inclusions in forsterite. The groundmass consists of microlites of plagioclase and very fine interstitial grains of augite and diopside. The mean chemical composition of these basalts is as follow: $15.9 \%$ of $\mathrm{Al}_{2} \mathrm{O}_{3}$, $13.5 \%$ of $\mathrm{Fe}_{2} \mathrm{O}_{3}$ and $44.6 \%$ of $\mathrm{SiO}_{2}$ [15] (cf. Table 3).

\subsection{Analysis Methods}

The study of the Doumbouo-Fokoué bauxite indices were conducted at four different scales: landscape, pedons, thin section and sample.

The landscape study refers to the bauxite reserves mapping. It was based on preliminary works which consisted at drawing and overlapping geological and morphological maps of the Doumbouo-Fokoué region using GIS (geographic information systems), with the resultants detailed geomorphologic map of the study area. Cartography of the bauxitic mantles was based on data collected during field works. Data correspond to bauxitic samples and their sampling sites coordinates which were afterwards projected onto the geomorphologic map using GIS to demarcate the bauxitic plateaus.

Pedons study is based on the field soil morphological description method [16]. It was performed on road cuts, quarries and pits. After what, bauxitic samples were collected for laboratory analyses.

Laboratory analyses concern microscopic, mineral and chemical analysis.

Concerning microscopic analysis, non disturbed bauxitic samples were hardened using epoxy resin, sharpened and polished to obtain thin sections for microscope description.

Minerals were determined using X-ray diffraction (XRD) and thermo-gravimetric analysis (TGA). X-ray diffraction was performed on $0.2 \mathrm{~mm}$ bauxitic powder using BRUKER diffract-meter according to the following conditions: copper anode $(\mathrm{Cu}-\mathrm{K} \alpha)$, wavelength, $\lambda$ : $1.5418 \AA$, scanning speed: $0.002^{\circ} / \mathrm{s}$, scan range: $5^{\circ}-70^{\circ}$, drive axis $2 \theta$. Thermo-gravimetric analysis consists in the evaluation of the weight loss of bauxitic powder during an increasing temperature (up to $900^{\circ} \mathrm{C}$ ). Minerals were identified and their relative abundance calculated using percentage of weight loss in a defined interval of temperature [17].

Chemical elements determination was performed using X-ray fluorescence on bauxitic powder crushed and sieved into $0.2 \mathrm{~mm} .300 \mathrm{mg}$ of bauxitic powder were fused with $900 \mathrm{mg}$ of lithium meta-borate $\left(\mathrm{LiBO}_{2}\right)$ during $1 \mathrm{~h}$ at $980^{\circ} \mathrm{C}$, and dissolved into $1.55 \mathrm{M}$ of nitric acid. Chemical elements are quantified using ICP-AE spectrometry for major elements and FI-ICP-M spectrometry for trace elements.

\subsection{Calculation Methods}

Enrichment-depletion of elements in bauxitic facies was assessed using enrichment factors $(E F)$. $E F$ which is the ratio between the content of an element in any given bauxitic facies and that of the parent rock has been calculated using the relation: $E F(X)=(X i / R i) /(X s / R s)$ [18]. In this relation $X i$ and $R i$ are the concentrations of the element of interest and immobile element (Ti) and $X s$ and $R s$ are the concentrations of the same elements in the 
parent rock.

Bauxite reserves were also calculated using the following formula: $M=S \times H \times D a$, where $S$ is the total bauxitic plateaus surface, $H$ the mean thickness of bauxitic mantles and $D a$ the bulk densities of the bauxitic facies.

\section{Results}

\subsection{Landscape Distribution of Bauxitic Mantles in Doumbouo-Fokoué}

Fourteen bauxitic plateaus have been identified in Doumbouo-Fokoué (Figure 2). All are made up of thick bauxitic mantles stretching out for kilometers at the summit and upper slopes of interfluves. They have been subdivided into two main bauxitic provinces: the Doumbouo and Fokoué bauxitic provinces.

The Doumbouo bauxitic province spreads out north of the locality and covers about three quarters of the area. In this area, the bauxitic mantles cover a surface area of 5.1 $\mathrm{km}^{2}$, which represents about $89 \%$ of the bauxitic surface. It is thus the most abundant bauxite ores deposits in
Doumbouo-Fokoué. It consists of ten bauxitic plateaus called bowal that are organized into large interfluves with summit capped with bauxitic mantles and surrounded by steep slopes. They are thus characteristic of regions with contrasted climate. They are: Tsingla, Sa' a, Ngwa, Letagli, Doumbouo, Letet1, Letet2, Tougong, Honto and Meka plateaus. The Tsingla plateau shows a forked bauxitic mantle belt of about $2.5 \mathrm{~km}$ long (Figure 2). The $S a^{\prime} a$ plateau consists of a branching bauxitic mantle with about $3.5 \mathrm{~km}$ long. The $N g w a$ plateau corresponds to a small bauxitic mantle strip (less than $1 \mathrm{~km}$ long) near the $S a^{\prime}$ a plateau. The Doumbouo plateau shows a bauxitic mantle belt with more than $4 \mathrm{~km}$ long in the NE area. The Letet 1 , Letet 2 and Letagli plateaus occur in the centre of the area and consist of pockets of bauxitic mantles not exceeding $1 \mathrm{~km}$ wide. The Honto, Tougong and Meka plateaus correspond to the bauxitic mantle belts stretching out on $3 \mathrm{~km}, 1.5 \mathrm{~km}$ and $2 \mathrm{~km}$ respectively.

The Fokoue province is located in the southern part of the region and covers only a surface area of $0.6 \mathrm{~km}^{2}$ (Figure 2). It is thus the least abundant bauxite ores deposits

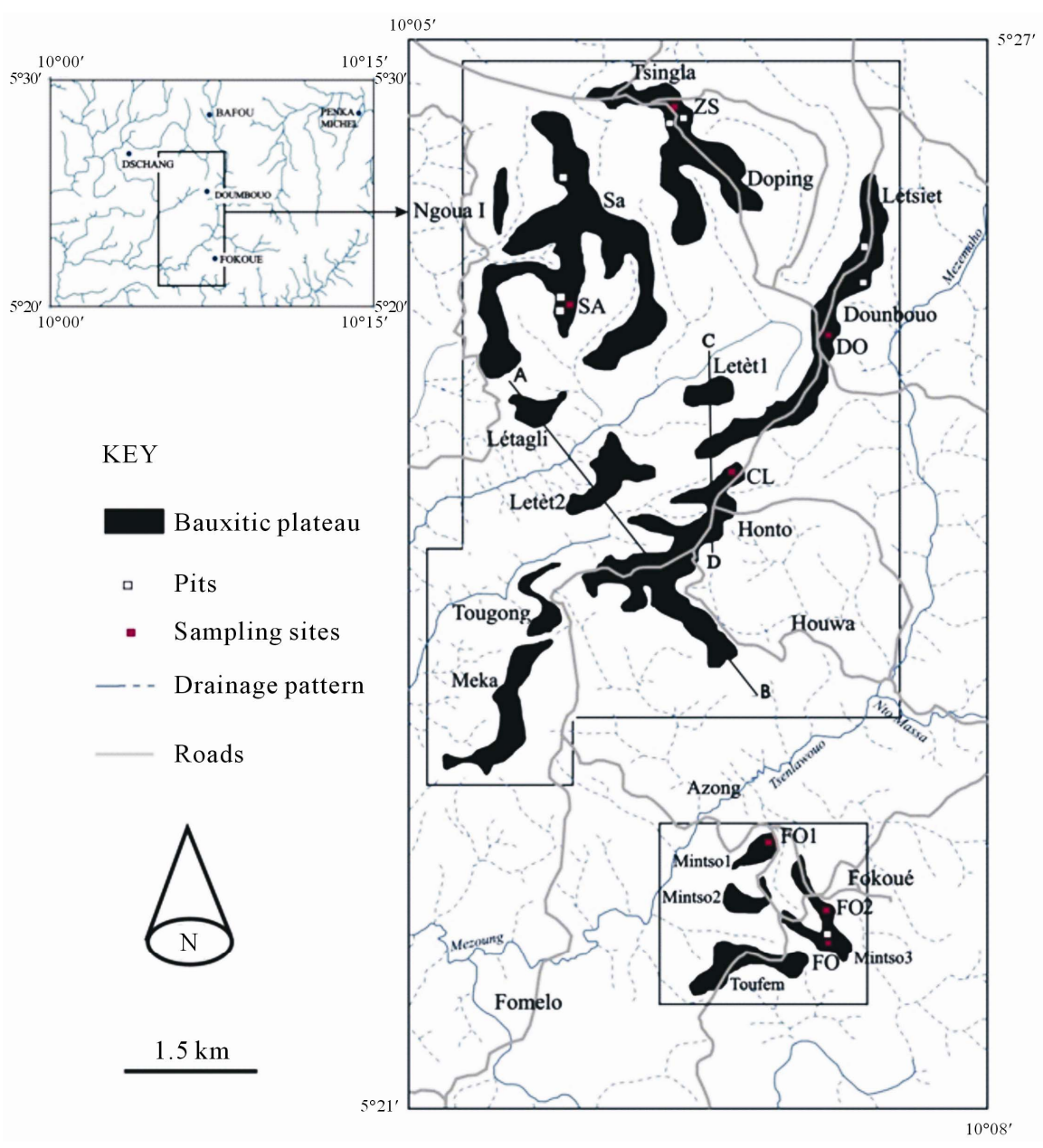

Figure 2. Landscape distribution of bauxitic mantles in Doumbou-Fokoué. 
in this region. It is made up of four bauxitic plateaus also organized into bowal. They are: Mintso1, Mintso2, Mintso3 and Toufem plateaus. The Mintso1 and Mintso2 plateaus consist of pockets of bauxitic mantles not exceeding $1 \mathrm{~km}$ wide. The Mintso3 plateau is a V-shape bauxitic mantle with $1.5 \mathrm{~km}$ long. The Toufem plateau shows a bauxitic mantle belt with $1.5 \mathrm{~km}$ long.

\subsection{Bauxitic Pedons in Doumbouo-Fokoué}

Eight (8) bauxitic pedons were selected in Doumbouo-Fokoué for morphological description (Figure 3). They are PZ1 and PZ2 pedons from the Tsingla bauxitic plateau; PS1, PS2 and PS3 pedons from the $S a$ ' $a$ bauxitic plateau; PD1 and PD2 pedons from the Doumbouo

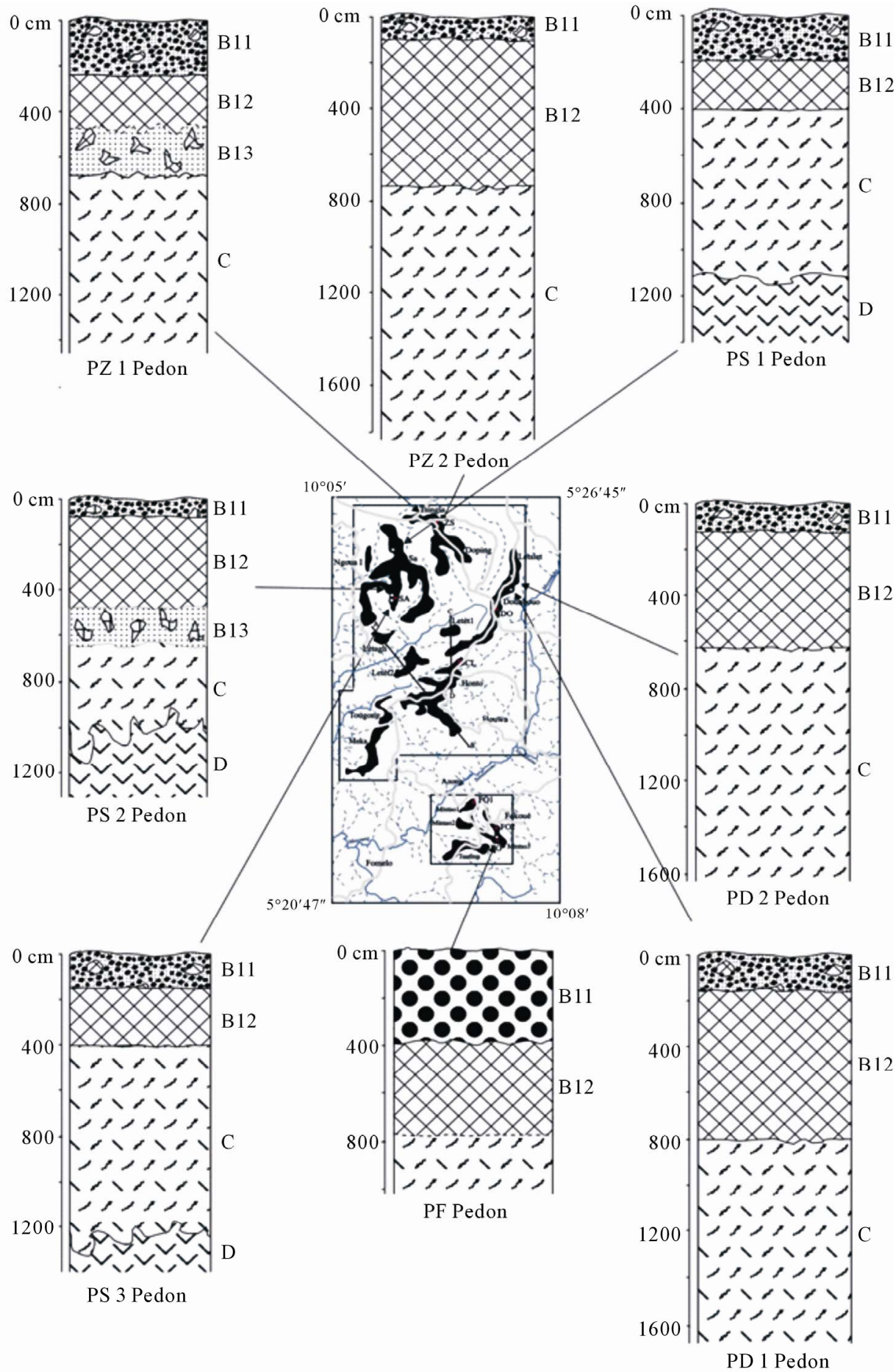

Figure 3. Bauxitic pedons in doumbouo-fokoué. 
bauxitic plateau; and PF pedon from the Mintso3 bauxitic plateau. Macroscopic organization and morphological characteristics of these bauxitic pedons are presented in Figure 3 and Table 1 respectively.

In Doumbouo-Fokoué, all bauxitic pedons are located on slightly sloped crests $(1 \%-2 \%)$, between 1532 and $1590 \mathrm{~m}$ asl. They correspond to deep weathered soil profiles (10.0 to $12.0 \mathrm{~m}$ thick and more) with very thick bauxitic B horizon ( 4.0 to $8.0 \mathrm{~m}$ ) lying over a saprolite C horizon (Figure 3). The uppermost and very thick bauxitic $\mathrm{B}$ horizon corresponds to the bauxitic mantle and is subdivided into $\mathrm{B}_{11}, \mathrm{~B}_{12}, \mathrm{~B}_{13}$ and $\mathrm{B}_{14}$ sub-horizons. The $B_{11}$ sub-horizon varies from 70 to $240 \mathrm{~cm}$ thick and is made up of bauxitic nodules and fragments embedded into a loose fine earth. The loose fine earth is dark red (2.5YR3/6), clayey sand, fragile, fine granular and friable. The bauxitic nodules and fragments represent $40 \%$ to $45 \%$ in volume of the sub-horizon. They are made up of red $(10 \mathrm{R} 4 / 6)$, very hard and more or less differentiated bauxitic matrix. The $\mathrm{B}_{12}$ sub-horizon has 200 to $650 \mathrm{~cm}$ thick. It is a continuous bauxitic duricrusts consisting of non differentiated, very hard and red (10R4/6) bauxitic matrix interrupted with yellow red (5YR4/8) and fairly hard streaks. Its lower boundary is distinct and irregular when lying on $\mathrm{B}_{13}$ sub-horizon, diffuse and regular on the contrary when lying on the saprolite $\mathrm{C}$ horizon. The $\mathrm{B}_{13}$ sub-horizon is poorly represented (only in PZ1 and PS2 bauxitic pedons) (Figure 3 and Table 1), thin (less than $200 \mathrm{~cm}$ ) and made up of discontinuous bauxitic fragments embedded into fine earth. The fine earth is clayey, pale red (2.5YR4/8), fragile, coarse granular and firm. The bauxitic fragments do not exceed $30 \%$ in volume. They show yellow red (7.5YR6/6), fairly hard and non differentiated bauxitic matrix. The $\mathrm{B}_{14}$ sub-horizon is also poorly represented (only in PF pedon) (Figure 3 and Table 1). It always lies over the $B_{12}$ sub-horizon when exists and corresponds to a $400 \mathrm{~cm}$ thick and continuous bauxitic duricrusts made up of very hard, dark red (2.5YR3/6) and interstitial bauxitic matrix surrounding numerous yellow red (7.5YR6/8) bauxitic nodules.

\subsection{Bauxitic Facies in Doumbouo-Fokoué}

Two main bauxitic facies were identified in Doumbouo-Fokoué: the saprolite and the pisolith bauxitic facies. The saprolite bauxitic facies is the most abundant bauxitic facies in Doumbouo-Fokoué. It is observed in all bauxitic pedons where it corresponds to the bauxitic duricrusts in $\mathrm{B}_{11}, \mathrm{~B}_{12}$ and $\mathrm{B}_{13}$ sub-horizons (Figure 3 and Table 1). The pisolith bauxitic facies is the least abundant and corresponds to the continuous bauxitic duricrusts in $\mathrm{B}_{14}$ sub-horizon.

The two bauxitic facies were characterized on macroscopic, microscopic, mineral and geochemical point of view. The main results are summarized below.

Macroscopically, the saprolite bauxitic facies exhibits continuous, very hard and dark red to yellow red (10R4/6 to 7.5 YR6/8) bauxitic matrix scattered by numerous micrometric cavities and white grey punctuations (Figure 4(a)). The pisolith bauxitic facies is made up of interstitial bauxitic matrix surrounding more or less differentiated bauxitic nodules (Figure 4(b)). The interstitial bauxitic matrix is non differentiated, continuous, very hard, dark reddish brown to yellow red $(2.5 \mathrm{YR} 3 / 6$; 7.5YR6/6), and contains micrometric white grey spots like in the saprolite bauxitic facies. The bauxitic nodules represent more than $35 \%$ in volume of the pisolith bauxitic facies. They display non differentiated, very hard and pale red to dark reddish brown (5YR6/8; 2.5YR3/6) internal bauxitic matrix rimmed by dark red $(2.5 \mathrm{YR} 3 / 2)$ and differentiated cortex.

Optic microscopy reveals that the saprolite bauxitic facies is a reddish brown porphyric s-matrix with both clay- and crystal-rich plasmas (Figure 4(c)). The clay-rich plasma has insepic and plasmic fabric and corresponds to a brown red ferruginous matrix dissected by a network of micro-cracks. Locally, this plasma is superimposed on the crystal-rich plasma. The crystal-rich plasma has a crystallic b-fabric with whitish grey well developed crystals of gibbsite infilling micro-cracks (Figure 4(c)) or present as individual domains under the clay-rich plasma. This s-matrix is very porous, with packing and planar voids. The pedic features refer to the micro-particles with undulic to isotic b-fabric and the well developed banded cutans with alternate layers of ferrans and gibbsitans. In the pisolith bauxitic facies, two bauxitic domains were identified: the interstitial bauxitic matrix and the bauxitic nodules (Figure 4(d)). The interstitial bauxitic matrix represents less than $5 \%$ in volume. It shows the same microscopic organization like in the saprolite bauxitic facies, with porphyric and very porous s-matrix. The bauxitic nodules are very abundant (around $45 \%$ in volume) and have spherical to sub-spherical shape, with mean diameter varying from $1 \mathrm{~mm}$ to $1.5 \mathrm{~cm}$.

Their internal matrix also shows the same microscopic organization like in the saprolite bauxitic facies. But, the striking features of these bauxitic nodules remain the presence of continuous, well differentiated, dark red and thin $(0.08$ to $0.125 \mathrm{~mm}$ ) bauxitic cortex (Figure $4(\mathrm{~d})$ ). They are thus bauxitic pisoliths.

From a mineral point of view, the saprolite bauxitic facies contains predominantly gibbsite and hematite (Table 2). Gibbsite is the most abundant mineral, and represents $68.1 \%$ of minerals detected by X-ray. In XRD diagram (Figure 5), its major peak at $4.84 \AA$ (not shown) suggests a well crystallized mineral. Hematite is also significant and represents $31.9 \%$ of minerals detected by X-ray. 
Table 1. Morphological characteristics of bauxitic pedons.

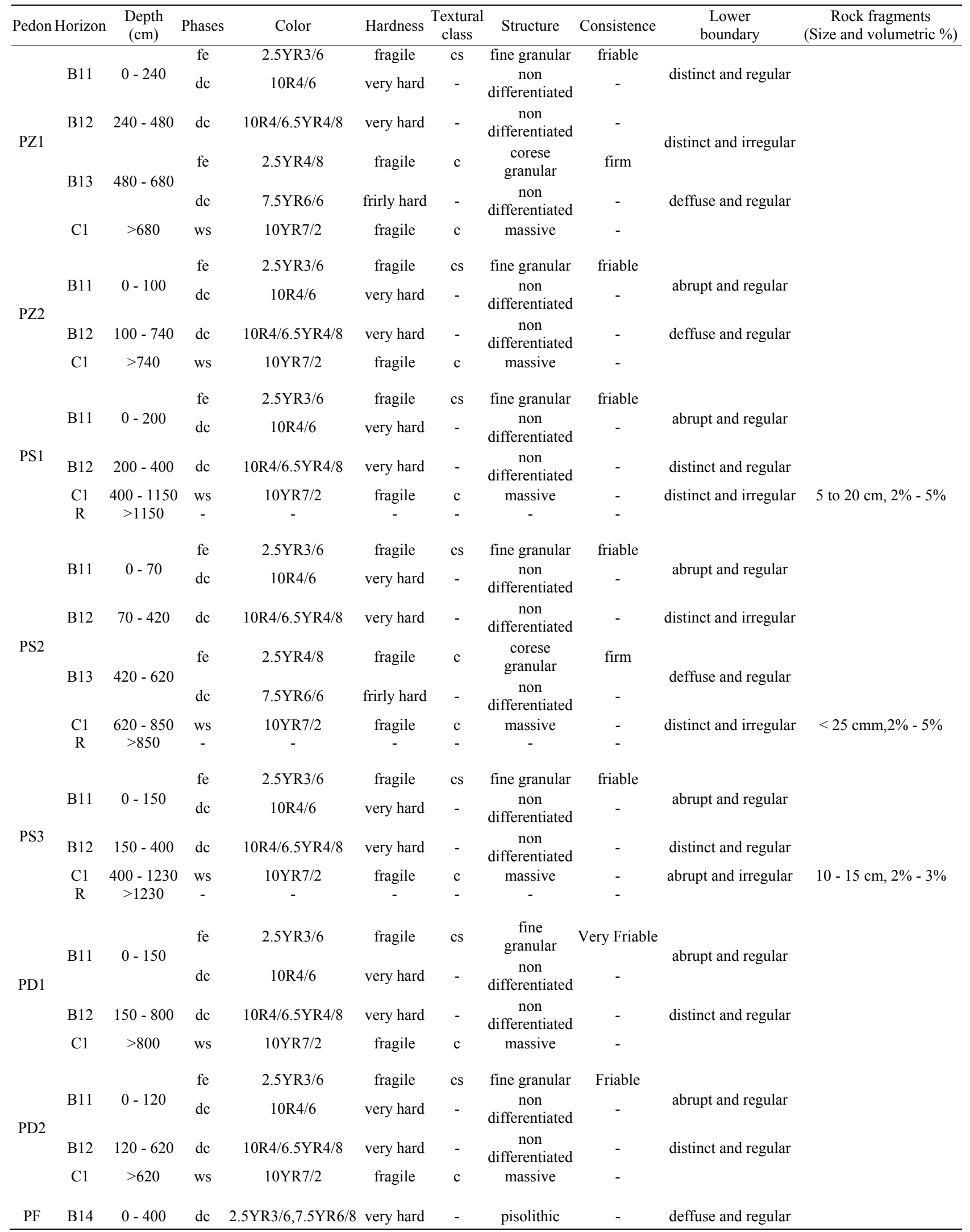

Phases: fe, fine earth; dc, duricrust; ws, weathered saprolite. Textural class: c, clay; cs, clay sand. 


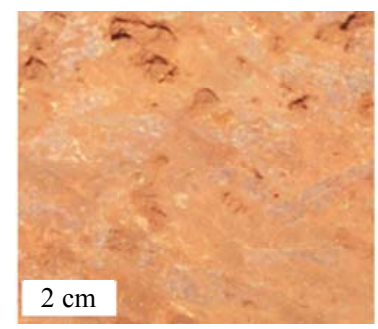

(a)

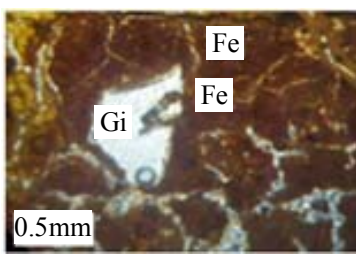

(c)

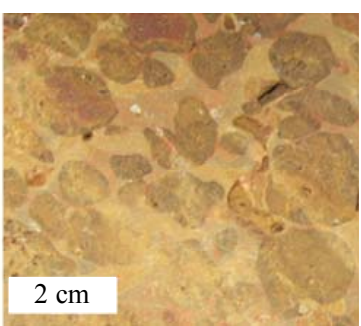

(b)

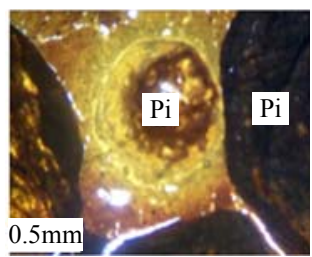

(d)

Figure 4. Macroscopic and microscopic organization of bauxitic facies. Fe: clay rich plasma with ferruginous matrix; Gi: crystal rich plasma with whitish grey crystals of gibbsite; Pi: pisolith. (a) Saprolite bauxitic; (b) Pisolith bauxitic facies facies; (c) Microscopic view of the saprolite; (d) Microscopic view of the pisolith facies.

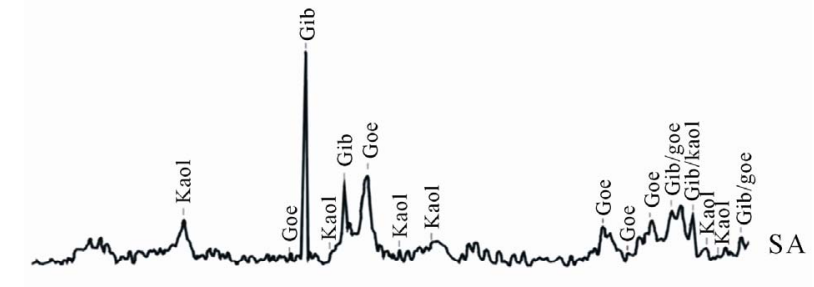

훙

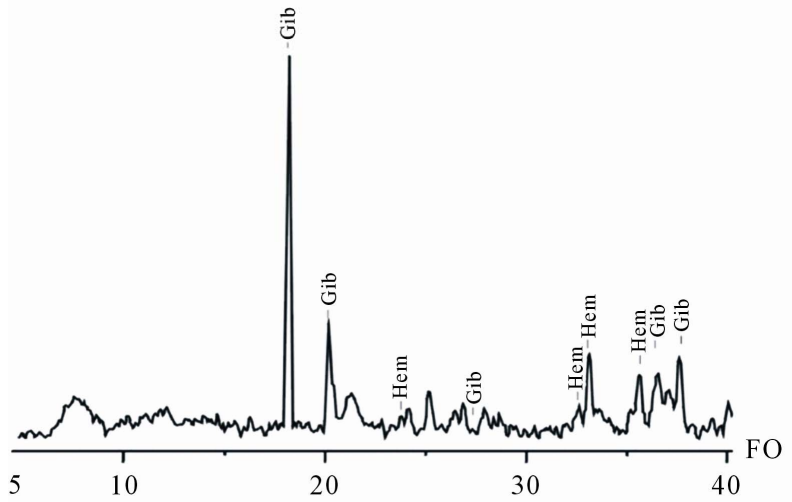

Figure 5. X-ray patterns of bauxitic facies. FO: saprolite bauxitic facies; SA: pisolith bauxitic facies; Kaol: kaolinite; Gib: gibbsite; Hem: hematite; Goe: goethite.

Table 2. Minerals composition of bauxitic facies. nd, non detected; - , rare; + , fairly common; ++++ very abundant.

\begin{tabular}{|c|c|c|c|c|c|c|c|}
\hline \multirow{2}{*}{ Bauxitic facies } & \multicolumn{4}{|c|}{ minerals detected by CRD abundance in \% } & \multicolumn{3}{|c|}{ minerals dectected by TGA relative abundance } \\
\hline & Kaolinite & Gibbsite & Goethite & Hematite & Kaolinite & Gibbsite & Goethite \\
\hline Pisolithic bauxite & 23.9 & 48.6 & 27.5 & nd & + & +++ & + \\
\hline Saprolitic bauxite & nd & 68.1 & nd & & - & ++++ & - \\
\hline
\end{tabular}

Its major peak is at $3.67 \AA$ (not shown). Traces of kaolinite and goethite were also detected by TGA (Table 2), but not by XRD due to their very low concentrations. In the pisolith bauxitic facies, mineral association includes gibbsite, goethite and kaolinite (Table 2). Gibbsite is still the most abundant mineral, though amounting only $48.6 \%$ of minerals detected by X-ray. Its major peak also appears at $4.84 \AA$ (not shown). Goethite is the second most abundant mineral in this facies, and represents $27.5 \%$ of minerals detected by X-ray. Its major peak at $4.16 \AA$ confirms the significant Al substitution (6.5\% of $\mathrm{AlOOH})$. Kaolinite is also present $(23.9 \%$ of minerals detected by X-ray). Its major peak at $7.15 \AA$ (not shown) suggests that this mineral is well crystallized. The low gibbsite content and the total lack of hematite of the pisolith bauxite facies are the main features segregating the two bauxitic facies. Aluminium is the most abundant chemical element in these bauxitic facies (Table 3), with $49.49 \%$ and $47.49 \%$ of $\mathrm{Al}_{2} \mathrm{O}_{3}$ respectively in the saprolite and the pisolith bauxitic facies. It is followed by relatively high content of iron $\left(20.24 \%\right.$ and $22.33 \%$ of $\mathrm{Fe}_{2} \mathrm{O}_{3}$ respectively) and low to very low content of silica $(1.81 \%$ and
$7.66 \%$ of $\mathrm{SiO}_{2}$ respectively) and titanium $(2.91 \%$ and $2.00 \%$ of $\mathrm{TiO}_{2}$ respectively). In the saprolite bauxitic facies, the most abundant trace element is $\mathrm{Zr}$ with 1111 $\mathrm{mg} \cdot \mathrm{kg}^{-1}$, followed by $\mathrm{Cr}\left(616 \mathrm{mg} \cdot \mathrm{kg}^{-1}\right)$ and $\mathrm{Nb}(105$ $\left.\mathrm{mg} \cdot \mathrm{kg}^{-1}\right)$. In the pisolith bauxitic facies, the most abundant is unlike $\mathrm{Cr}$ with $1916 \mathrm{mg} \cdot \mathrm{kg}^{-1}$, followed by $\mathrm{Zr}(666$ $\left.\mathrm{mg} \cdot \mathrm{kg}^{-1}\right), \mathrm{V}\left(224 \mathrm{mg} \cdot \mathrm{kg}^{-1}\right), \mathrm{Zn}\left(80 \mathrm{mg} \cdot \mathrm{kg}^{-1}\right)$ and $\mathrm{Nb}(35$ $\left.\mathrm{mg} \cdot \mathrm{kg}^{-1}\right)$. In comparison with the parent rock (basalt) (Table 3), one notes a drop of the silica contents (44.61 to $1.81 \%$ of $\mathrm{SiO}_{2}$ ) and a total exportation of alkali and alkaline earths in bauxitic facies. Inversely, aluminium, iron and some trace elements contents increase very significantly $\left(\mathrm{Al}_{2} \mathrm{O}_{3}: 15.91 \%\right.$ to $49.49 \% ; \mathrm{Fe}_{2} \mathrm{O}_{3}: 13.52 \%$ to $22.33 \%$; Cr: 9 to $1916 \mathrm{mg} \cdot \mathrm{kg}^{-1}$; $\mathrm{Zr}: 370$ to $1111 \mathrm{mg} \cdot \mathrm{kg}^{-1}$ and $\mathrm{Nb}: 82$ to $\left.105 \mathrm{mg} \cdot \mathrm{kg}^{-1}\right)$. The iso-titanium geochemical balance calculation based on the enrichment factor $(E F)$ evaluation between fresh rock and the bauxitic facies (Table 3) shows that the most enriched element in these bauxitic facies is Cr with $E F$ equal to 96 and 435 in the saprolite and the pisolith bauxitic facies respectively, followed by $\mathrm{Al}$ ( $E F: 4.37$ and 6.10 respectively), $\mathrm{Zr}$ ( $E F: 4.22$ and 3.68 respectively), $\mathrm{Fe}(E F: 2.10$ and 3.38 respec- 
tively) and $\mathrm{Nb}$ (EF: 1.80 and 0.87 respectively) (Table 3).

\section{Discussions}

\subsection{The Doumbouo-Fokoué Bauxite}

Two bauxitic facies were identified in Doumbouo-Fokoué: the saprolite and the pisolith bauxitic facies. Each bauxitic facies has high aluminium contents (49.49 and $47.49 \%$ of $\mathrm{Al}_{2} \mathrm{O}_{3}$ respectively) and low to very low silica contents $\left(1.81 \%\right.$ to $7.66 \%$ of $\left.\mathrm{SiO}_{2}\right)$. This evidences a real bauxite ore in Doumbouo-Fokoué [2]. In addition, the bauxitic mantles in this region cover a surface area of approximately $5.7 \mathrm{~km}^{2}$; with a mean thickness of $6.30 \mathrm{~m}$ and bulk densities of $2.28 \mathrm{~g} \cdot \mathrm{cm}^{-3}$ and $2.09 \mathrm{~g} \cdot \mathrm{cm}^{-3}$ respectively in each facies. In some respects, these bauxitic mantles constitute approximately 9.2 millions tons of bauxite reserves, and thus can be classified as an important bauxite ore deposit. Since it is located close (less than 20 $\mathrm{km}$ ) to the Fongo-Tongo bauxite ore deposit it may constitute a real additional income. The bauxitic facies in Doumbouo-Fokoué shows macroscopically white grey micrometric punctuations which represent completely weathered plagioclases. Optic microscopy reveals that plagioclases and forsterites are replaced with respect to their volume and shape (pseudomorphosis) by gibbsite and iron bearing minerals respectively. These parent rock remaining features indicate that the Doumbouo-Fokoue bauxite preserved saprolitic nature and then corresponds to ortho-bauxites [19]. The [Fe - Clay - (Al + Ti)] minerals diagram (not shown) and relatively high Fe contents (20.24\% and $22.33 \%$ of $\mathrm{Fe}_{2} \mathrm{O}_{3}$ respectively) note that they belong to iron rich bauxite [1]. Thus, the bauxite ore deposits in Doumbouo-Fokoué can be classified as the iron bearing lateritic ortho-bauxites.

In Doumbouo-Fokoué bauxitic facies, very abundant silica leaching ( $E F: 0.06$ and 0.35 ), total exportation of alkali and alkaline earths ( $E F$ close to 0.00$)$ and important aluminium enrichment ( $E F: 4.37$ and 6.10) as well as abundant accumulation of gibbsite suggest that bauxitization in this environment may correspond to intense hydrolysis leading to allitization [20]. Allitization, which refers to lateritization process, may be related to abundant rainfall (1755 mm of mean annual rainfall), dense and dendritic hydrographic network and steep slopes which favoured a highly leaching milieu [21]. Thus, lateritization in Doumbouo-Fokoué favoured bauxitization through aluminium mobilization [22] with individualization of the iron bearing lateritic ortho-bauxites which develop thick bauxitic mantles. In these bauxitic mantles, the saprolite bauxitic facies is located at the bottom, below the pisolith bauxitic facies. This vertical organization of the bauxitic facies suggests that the pisolith bauxitic facies likely derive from the saprolite bauxitic facies during geochemical and mineral individualization of bauxitic pisoliths with formation of bauxitic cortex [23], transformation of hematite into goethite and part of gibbsite into kaolinite [24].

\subsection{Implication of the Doumbouo-Fokoué Bauxitic Mantles to the Relief Lowering}

In the West and Central Africa, many works focused on vertical organization and landscape distribution of the bauxitic mantles and their implication to the landscape evolution $[1,4,8,9,23,25-27]$. They note that these bauxitic mantles are regularly located at the summit of interfluves where they form an old and residual surface dominated by a saprolite bauxitic facies and named African surface by Valeton [1]. These initial bauxitic mantles were probably formed during early to low Miocene under contrasted climate [28] in an oxidizing-leaching milieu which favoured crystallization of hematite instead of goethite [29]. Thus, the initial relief in DoumbouoFokoué likely correspond to this old and continuous bauxitic mantle surface slightly slopped southwards which consisted of hematite-rich saprolite bauxitic facies (Figure 6(a)).

Since the upper Miocene, the old and continuous bauxitic surface was subject to a generalized degradation process [25] resulting into the separation of individual

Table 3. Major and trace elements contents of bauxitic facies and their enrichment factor (EF).

\begin{tabular}{|c|c|c|c|c|c|c|c|c|c|c|c|c|c|c|c|}
\hline \multirow[t]{2}{*}{ Bauxitic facies } & & \multicolumn{9}{|c|}{ Major elements (\%) } & \multicolumn{5}{|c|}{ Trace elements $\left(\mathrm{mg} \cdot \mathrm{kg}^{-1}\right)$} \\
\hline & & $\mathrm{SiO}_{2}$ & $\mathrm{Al}_{2} \mathrm{O}_{3}$ & $\mathrm{Fe}_{2} \mathrm{O}_{3}$ & $\mathrm{TiO}_{2}$ & $\mathrm{Cao}$ & $\mathrm{MgO}$ & $\mathrm{K}_{2} \mathrm{O}$ & $\mathrm{Na}_{2} \mathrm{O}$ & LOI & $\mathrm{Cr}$ & $\mathrm{Zr}$ & $\mathrm{V}$ & $\mathrm{Zn}$ & $\mathrm{Nb}$ \\
\hline Pisolithic facies & SA & 7.66 & 47.49 & 22.33 & 2.00 & 0.01 & 0.06 & 0.01 & 0.00 & 18.30 & 1916 & 666 & 224 & 80 & 35 \\
\hline Saprolitic facies & $\mathrm{FO} 2$ & 1.81 & 49.49 & 20.24 & 2.91 & 0.00 & 0.00 & 0.00 & 0.00 & 24.6 & 616 & 1111 & 0 & 0 & 105 \\
\hline Parent rock (basalt) & $\mathrm{SA}$ & 0.35 & 6.10 & 3.38 & & 0.00 & 0.02 & 0.01 & 0.00 & & 435 & 3.68 & - & - & 0.87 \\
\hline \multirow[t]{2}{*}{ Enrichment factor (EF) } & $\mathrm{FO} 2$ & 0.06 & 4.37 & 2.10 & & 0.00 & 0.00 & 0.00 & 0.00 & & 96 & 4.22 & - & - & 1.80 \\
\hline & $\mathrm{Ba}$ & 1.00 & 1.00 & 1.00 & & 1.00 & 1.00 & 1.00 & 1.00 & & 1.00 & 1.00 & - & - & 1.00 \\
\hline
\end{tabular}




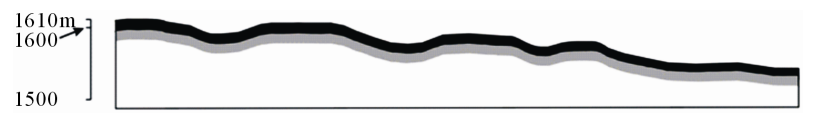

(a)

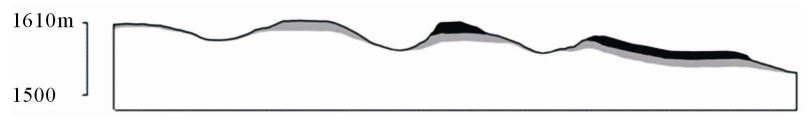

(b)

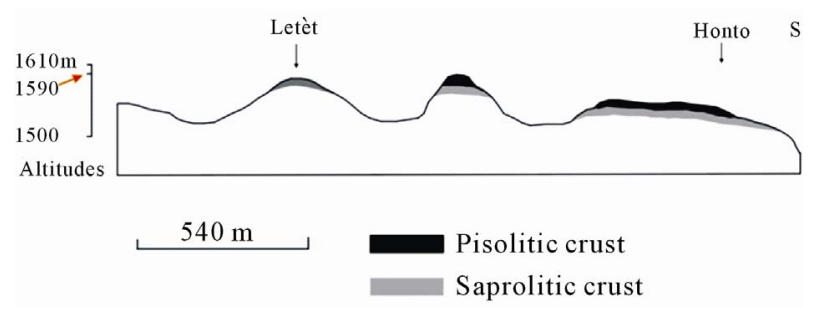

(c)

Figure 6. Landscape lowering of the Doumbouo-Fokoué bauxitic mantles.

bauxitic plateaus. This degradation process was favoured by humid equatorial climate [30] and tectonic instability [31] of the region which belongs to the Cameroon volcanic line. It firstly refers to the late Miocene tectonic activities along the Cameroon volcanic line [15] that contributed to the dislocation of this African surface and its abandonment to intense erosion processes [32]. It also refers to the transformation at topsoil of the saprolite bauxitic facies into the pisolith bauxitic facies during individualisation of pisoliths [33], originating a thick bauxitic mantle with pisolithic facies overlying the saprolite bauxitic facies (Figure 6(a)). It also refers to regressive erosion favoured by the dense hydrographic network which strongly incised the African surface into large and elongated bauxitic plateaus surrounded by deep and profound valleys (Figure 6(b)). It also concerns deferruginization at topsoil of the bauxitic mantles where iron bearing secondary minerals are preferably dissolved in a highly leaching milieu [21] as indicated by the drop of $\mathrm{Fe}_{2} \mathrm{O}_{3}$ contents (not shown) in fine earth [34,35]. This originated at topsoil a gravelled light soil horizon consisting of bauxitic pisoliths and fragments embedded into clayey fine earth $[23,36]$. The gravelled light soil horizon develops downward at the expense of the bauxitic mantles. At the same time at topsoil, it is subject to surface erosion [32]. Both processes act together and cause significant reduction of the bauxitic mantles thickness [34,35,37]. Lastly, the bauxitic mantle degradation in Doumbouo-Fokoué refers to mechanical erosion that causes around the plateaus dismantling of the bauxitic mantles into bauxitic blocks which move down-slopes, inducing bauxitic mantles to reduce in size [8]. All these degradation processes acted together at different scales and contributed to lower the relief in this area. So, since the upper Miocene, in Doumbouo-Fokoué, the bauxitic mantles undergo generalized degradation under humid conditions which results into individualization of slightly undulated bauxitic plateaus completely overlapped to the Bamiléké plateau and then, contributed to general levelling of the relief in this region (Figure 6(c)). These demonstrations allow relating this bauxitic mantle to the other bauxitic mantles of the African surface (Adamaoua and Bangam in Cameroon, Guinea, Burkina Faso, Ivory Coast and Nigeria) and then to explain the general lowering of this African surface as noted in the Central and West Africa [1,25].

\section{Conclusions}

In Doumbouo-Fokoué, important bauxite ore deposits were developed from basaltic rocks during early to lower Miocene under contrasted climates. They correspond to the iron bearing lateritic ortho-bauxite ore deposits with 9.2 millions tons of bauxite reserves. These lateritic bauxites are differentiated into pisolith bauxitic facies locally overlying saprolite bauxitic facies. They form thick bauxitic mantles at the summit of interfluves which have individualized fourteen bauxitic plateaus (bowé). The evolution of the landscape attributed to the bauxitic mantles development in Doumbouo-Fokoué differentiates three major stapes:

- Development of the old and residual bauxitic surface (African surface) during the early to lower Miocene by intense bauxitization process under contrasted climates;

- Intense degradation of the African surface favoured by regressive erosion, deferruginization and mechanical dismantling of the bauxitic mantle under humid sub-equatorial climate;

- General lowering of the relief under the control of the above degradation processes and the joining up of this relief with the Bamiléké plateau.

Thus, bauxitic mantles in Doumbouo-Fokoué, through their landscape distribution, their vertical organization and bauxitic facies evolution, have contributed significantly to the general levelling of the Bamiléké plateau in the West Cameroon Highlands.

\section{REFERENCES}

[1] I. Valeton, "Saprolite-Bauxite Facies of Ferralitic Duricrusts on Palaeosurfaces of Former Pangaea," In: M. Thiry and R. Simon-Coincon, Eds., Palaeoweathering, Palaeosurfaces and Related Continental Deposits, International Association of Sedimentology, Vol. 27, 1999, pp. 153- 188.

[2] G. Bardossy, G. Aleva and G. J. J. Lateritic Bauxites, "Developments in Economic Geology," Elsevier, Amsterdam, 
1990, pp. 27, 624.

[3] E. Lee Bray, "US Geological Survey, Mineral Commodity Summaries," United States Government Printing Office, Washington, 2009.

[4] B. Kobilseck, "Géochimie et Pétrographie des Bauxites Latéritiques d'Amazonie Brésilienne, Comparaison Avec l'Afrique, l'Inde et l'Australie," Thèse Université Louis Pasteur, Strasbourg, 1990.

[5] W. Edlinger, "Contribution to Geology and Petrography of the German Adamawa," Ph.D. Thesis, Erlangen University, Erlangen, 1908, p. 125.

[6] S. Passarge, "The Superficial Structure and Geology of Cameroon," Annual Review of German Colonies, 1910, pp. 448-465.

[7] G. Weeksteen, "Preliminary Report on the Fongo Tongo Bauxite ore Deposits," Report of the Mine and Geology of the Cameroon State, 1957.

[8] S. M. Eno Belinga, "L'Altération des Roches Basaltiques et le Processus de Bauxitisation dans l'Adamaoua (Cameroun)," Thèse Doctorat Etat, Université Paris VI, Paris, 1972, p. 571.

[9] B. Hieronymus, "Study of the Weathering of Eruptive Rocks in the West Cameroon," Earth Science Thesis, University of Paris VI, Paris, 1985, p. 85.

[10] J. B. Nyobe, "A Geological and Geochemical Study of the Fongo-Tongo and Areally Related Bauxites Deposits," Ph.D. Thesis, Western Highlands, Camroon, 1987.

[11] M. Sojien, "Etude Pétrographique, Minéralogique et Géochimique des Formations Bauxitiques de Bangam dans les Hautes Terres de l'Ouest Cameroun," Thèse MSc., Université Dschang, Dschang, 2007, p. 77.

[12] P. Ntep, "Minerals Resources of the West Region SubDivisions," The Thematic Ores Resources Map of the Cameroon, Yaoundé, 2009.

[13] B. Deruelle, C. Moreau, R. Kambou, J. Lissom, E. Njonfang, R. T. Ghogomu and A. Nono, "The Cameroon Line: A Review," In: A. B. Kampuzu and R. T. Lubal, Eds., Magmatism in Extensional Structural Settings, Springer-Verlag, Berlin, 1991, pp. 274-327.

[14] M. Kwekam, J. P. Liégeois, E. Njonfang, P. Affaton and G. Hartmann, "Nature, Origin and Significance of the Fomopéa Pan-African High-K Calc-alkaline Plutonic Complex in the Central African Fold Belt (Cameroon)," Journal of African Earth Sciences, Vol. 57, 2010, pp. 79-95.

[15] D. G. Nkouathio, D. A. Kagou, J. M. Bardintzeff, P. Wandji, H. Bellon and A. Pouclet, "Evolution of Volcanism in Graben and Horst Structures Along the Cenozoic Cameroon Line (Africa): Implications for Tectonic Evolution and Mantle Source Composition," Mineralogy and Petrology, Vol. 94, 2008, pp. 287-303.

[16] R. Maignien, "Manuel Pour la Description des Sols sur le Terrain," Document ORSTOM, Paris, 1980, p. 112.

[17] D. Njopwouo, "Minéralogie et Physicochimie des Argiles de Bomkoul et de Balengou (Cameroun). Utilisation dans la Polymérisation du Styrène et Dans le Renforcement du Caoutchouc Naturel," Thèse Doctorat Etat, Université Yaoundé, Yaoundé, 1984, p. 300.
[18] K. A. Rahn and R. J. Mc Cafrey, "Compositional Differences between Arctic Aerosol and Snow," Nature, Vol. 280, 1979, pp. 479-480.

[19] B. Boulange, A. Carvalho and A. J. Melfi, "Geochemical Characteristics of African and Brazilian Bauxites Deposits: $\mathrm{SiO}_{2}-\mathrm{Al}_{2} \mathrm{O}_{3}-\mathrm{Fe}_{2} \mathrm{O}_{3}$ System and Ti, $\mathrm{Cr}, \mathrm{V}$ and $\mathrm{Fe}_{2} \mathrm{O}_{3}$ Relations," Geochemistry Earth Surface and Mineral Formation Symposium, 2-8 July 1990, Aix-en-Provence, pp. 30-32.

[20] G. Certini, M. J. Wilson, S. J. Hillier, A. R. Fraser and E. Delbos, "Mineral Weathering in Trachydacitic-Derived Soils and Saprolites Involving Formation of Embryonic Halloysite and Gibbsite at Mt Amiata, Central Italy," Geoderma, Vol. 133, No. 3-4, 2006, pp. 173-190.

[21] E. Aristizabal, B. Roser and S. Yokota, "Tropical Chemical Weathering of Hillslope Deposits and Bedrock Source in the ABURRA Valley, Northern Colombian Andes," Engineering Geology, Vol. 81, 2005, pp. 389-406.

[22] M. K. D. Mutakyahwa, J. R. Ikingura and A. H. Mruma, "Geology and Geochemistry of Bauxite Deposits in Lushoto District, Usambara Mountains, Tanzania," Journal of African Earth Sciences, Vol. 6, 2003, pp. 357-369.

[23] B. Boulange, "Les Formations Bauxitiques Latéritiques de Côte d'Ivoire," Travaux et Document ORSTOM, Vol. 175, 1984, p. 341 .

[24] J. Thorez, "Argilloscopy of Weathering and Sedimentation," Bulletin Société Géologique, Vol. 98, No. 2, 1989, pp. 245-267.

[25] J. C. Leprun, "Géochimie de Surface et Formes de Relief. IV. la Dégradation des Cuirasses Ferrugineuses. Etude et Importance du Phénomène Pédologique en Afrique de l'Ouest," Science Géologique Bulletin, Vol. 30, No. 4, 1977, pp. 265-273.

[26] Mazaltarim, "Géochimie des Cuirasses Bauxitiques de l'Afrique Occidentale et Centrale," Thèse Université Louis Pasteur, Strasbourg, 1989, p. 263.

[27] A. Bourdeau, "Les bauxites du Mali. Géochimie et Minéralogie," Thèse Université Louis Pasteur, Strasbourg, 1991, p. 329.

[28] A. Beauvais and Y. Tardy, "Degradation and Dismantling of Iron Crust under Climatic Changes in Central Africa," Chemical Geology, Vol. 107, No. *, 1993, pp. 277-280.

[29] Y. Tardy and D. Nahon, "Geochemistry of Laterites Stability of Al-Goethite, Al-Hematite and Fe-Kaolinite in Bauxites and Ferricretes: An Approach to the Mechanism of Concretion Formation," American Journal Sciences, Vol. 285, No. 10, 1985, pp. 865-903.

[30] Y. Tardy, A. J. Melfi and I. Valeton, "Climats et Paléoclimats Tropicaux Péri Atlantiques. Rôle des Facteurs Climatiques et Thermodynamiques (Température et Activité de l'Eau) sur la Répartition et la Composition Minéralogique des Bauxites et des Cuirasses Ferrugineuses au Brésil et en Afrique," Compte Rendu Académie Science, Vol. 306, No. 2, 1988, pp. 289-295.

[31] I. Valeton and A. J. Melfi, "Distribution Pattern of Bauxites in Cataguases Area (SE-Brazil) in Relation to Lower Tertiary Paleogeography and Younger Tectonics," Science Géologie Bulletin, Vol. 41, No. 1, 1988, pp. 85-98. 
[32] Y. Boulvert, “Aplanissement en Centrafrique. Relation avec le Cuirassement, la Tectonique, le Bioclimat. ProBlèmes Posés. Progrès des Connaissances," Bulletin Association Géographes Français, Vol. 4, 1985, pp. 301-309.

[33] G. J. Churchman, "The Alteration and Formation of Soil Minerals by Weathering. Handbook of Soil Science," M. E. Sumner, Ed., Handbook of Soil Science, CRC Press, Boca Raton, 2000, pp. 3-76.

[34] P. Tematio and K. R. Olson, "Characterization of Two Phases of Encrustment in a Sequence of Ferrallitic Soils in the South Cameroon and Its Effects on Landscape Evolution," Soil Sciences, Vol. 162, No. 10, 1997, pp. 758-766.

[35] E. Temgoua, D. Bitom, P. Bilong, Y. Lucas and H. R. Pfeifer, "Démantèlement des Paysages Cuirassés Anciens en
Zones Forestières Tropicales d'Afrique Centrale: Formation des Accumulations Ferrugineuses Actuelles en Bas de Ver- sants," Compte Rendu Géoscience, Vol. 334, No. 8, 2002, pp. 537-543.

[36] D. Bitom, B. Volkoff and M. Abossolo-Angue, "Evolution and Alteration in Situ of Massive Iron Duricrusts in Central Africa," Journal of African Earth Sciences, Vol. 37, 2003, pp. 89-101.

[37] P. Bilong, S. M. Eno Belinga and B. Volkoff, "Séquence D'évolution des Paysages Cuirassés et des Sols Ferrallitiques en Zones Forestières Tropicales d'Afrique Centrale. Place des Sols à Horizons d'Argile Tachetée," Compte Rendu Académie Science, Vol. 314, No. 2, 1992, pp. 109-115. 